\title{
Research on the Way to Realize the Function of Network Education in Ideological and Political Education
}

\author{
Yu Liu \\ News Center, Xi'an Peihua University, Xi'an, China
}

\begin{abstract}
In the new era, the target group of Ideological and political education in Colleges and universities is the indigenous people in the era of mobile Internet, whose dependence on the Internet is far greater than other groups. Therefore, it is necessary for colleges and universities to make full use of the Internet for ideological and political education. In today's free internet public opinion environment, how to guide college students to establish a correct world outlook, outlook on life, values, and constantly improve ideological awareness, enrich the campus cultural atmosphere is an important part of Ideological and political education in Colleges and universities.
\end{abstract}

Keywords: network education; ideological and political education; network platform.

\section{Introduction}

Colleges and universities undertake not only the important task of young college students' professional learning, but also the role of Ideological and political education. Facing the contemporary college students growing up with the network environment, how to achieve the goal of education in the new era is the top priority of political education in Colleges and universities.

\section{Research Ideas of Network Culture Education in Colleges and Universities}

The education of network culture in Colleges and universities should be guided by the basic theory of moral education and based on the reality of China's socialist modernization construction. First, the connotation, characteristics and changing laws of network culture in Colleges and universities are discussed. Then, the internal relationship between network culture in Colleges and universities and moral education is discussed. Finally, the motive force, direction and strategy of network culture in Colleges and universities, which is led by moral education, are given This paper makes a systematic and Empirical Study on the construction of campus network culture under the background of the integration of moral education and human resources.

In theory: keep up with the pace of the times, keep pace with the times, and constantly deepen the study and Research on morality cultivation. It is beneficial to enrich and perfect the basic theory of Ideological and political education, to deepen the research on the carrier of Ideological and political education, the connotation of network culture and the methods of Ideological and political education. The study of the construction of campus network strategy culture from the perspective of moral education is conducive to grasp the essence of the construction of campus network strategy culture, and promote the construction of campus network strategy culture education.

From the reality: how to integrate moral education into the construction of network culture in Colleges and universities will be conducive to the deep-rooted role of moral education in Colleges and universities, promote the healthy and harmonious development of network culture in Colleges and universities, and improve the moral sentiment and value level of teachers and students in Colleges and Universities. It is conducive to promoting the ideological and cultural construction and personnel training in China, building a harmonious, healthy and civilized campus network culture, and innovation of Ideological and political education in Colleges and universities. 
Table 1. difference analysis of satisfaction degree of Ideological and political education related projects in Colleges and universities $(\mathrm{P} \%)$

\begin{tabular}{cccc}
\hline Numble & Project & $\begin{array}{c}\text { Satisfied / Very } \\
\text { Satisfied }\end{array}$ & $\mathrm{P}$ \\
\hline $\begin{array}{c}\text { Educational } \\
\text { content }\end{array}$ & $\begin{array}{c}\text { The connotation of moral education is } \\
\text { close to the reality of society and life } \\
\text { Teachers' Ideological and political } \\
\text { quality }\end{array}$ & $75.0 / 25.0$ & 0.001 \\
Teachers' level & Teachers have spiritual expertise & $73.0 / 24.0$ & $<0.001$ \\
& Teacher's demeanor & $74.0 / 21.0$ & $<0.001$ \\
Form of & Can guide students to think & $78.0 / 25.0$ & 0.048 \\
Education & Combining theory with practice & $77.0 / 26.0$ & 0.028 \\
& & 0.005 \\
\hline
\end{tabular}

\section{Ways of Ideological and Political Education in Colleges and Universities}

\subsection{Theory Education and Building the First Classroom of University Education}

The main body of college education is professional education, so the realization of college education should be integrated into classroom teaching, strengthen the construction of students' theoretical knowledge, and give students professional vision and thinking to analyze and solve problems, which is the basis of Ideological and political work in the contemporary network public opinion environment. When establishing the system of situation and policy courses, employment guidance courses and military theory courses, we should combine the background of the times and social situation, set up classroom teaching contents according to the age, education background, hobbies, cognitive level and other aspects of the main body of college students, improve the pertinence, timeliness and affinity of the courses, and gradually establish a popular ideological and political course system for young students. Colleges and universities should pay more attention to ideological and political courses, improve supervision, incorporate credit assessment and other assessment standards, establish a perfect curriculum system, and grasp the main channel of Ideological Education in the classroom.

\subsection{Practice Education and Expand the New Vision of University Education}

Practical education is the key link of Ideological and political education and an important bridge between theory and action. At present, most colleges and universities in China have the status quo of emphasizing theory over practice and emphasizing achievement over ability. Overemphasizing the importance of book knowledge and the decisive role of examination results leads to the direct consequence that students lack practical ability and cannot apply what they have learned after entering the society. The jobs they finally find are often out of line with their majors, which goes against the original intention of choosing majors in universities. Colleges and universities should appropriately adjust the proportion of theoretical courses and practical courses, encourage students to "go out" and participate in social practice with the knowledge they have learned, so as to consolidate the theoretical basis, enrich their after-school cultural life, achieve the purpose of learning and give full play to the role of colleges and Universities in educating people.

\subsection{Cultural Education, Enriching the Profound Connotation of Theoretical Education}

Culture is the carrier of innovation activities. The five thousand years of Chinese profound culture carries forward positive energy, which can help college students to shape elegant temperament and cultivate noble character, and guide them to move forward towards healthy, sunny and upward path. Therefore, cultural education is endowed with important significance in today's era. Colleges and universities should call on students to learn traditional culture, learn the essence of Chinese excellent traditional culture, actively carry out campus cultural activities, community art festival, traditional 
culture salon and other student activities while learning cultural classics, so that students can understand the way of being human through practice. We should also carry out the education of socialist core values, and gradually make students establish cultural self-confidence through the youth horse learning class, party class, League class and other forms.

\subsection{Network Education to Meet the New Requirements of the Times}

Today's college students are closely related to the network in their study, work and life. The guidance of network public opinion is easy to lead and mislead students. Therefore, the premise of network education is to strengthen supervision. Colleges and universities should take the network as an important position of education, give full play to the right of participation and discourse of the network, and establish a high-quality network education mode. Flexible and novel network supervision mode can be adopted, such as recruiting students with network hobbies and specialties as network volunteers, supervising students' trends and collecting students' opinions and public opinions, so that colleges and universities can master the first-hand information of students' ideological trends in time; establishing ideological and political education website, opening network columns close to students' lives, such as counselor blog, professional forum, famous teacher forum, etc., to learn Students can take the way of online questions to have real-time dialogue with online guest teachers, improve students' participation and sense of existence, make every student feel care and concern, establish self-confidence on the network, and gradually bring self-confidence in the virtual environment of the network to real life, improve the confidence and motivation of learning, and also improve ideological awareness. For improving ideological and political work Working efficiency plays an important role. The recognition and growth of students is the ultimate goal of university education.

\section{The Way to Realize Ideological and Political Education Network Culture Education in Colleges and Universities}

\subsection{Optimize the Network Cultural Environment of Colleges and Universities, Inherit and Disseminate Excellent Traditional Culture}

Influenced by different regions and concepts, there are great differences in network culture, which also affects the campus network culture. Because each university has different educational ideas, so each university plays different roles in the campus network cultural environment. To purify and improve the network cultural environment, first of all, each university should make plans to optimize the network cultural environment according to its own situation, strengthen the construction and management of the campus network platform, enrich the network cultural content, and expand the network level Taiwan, purify the campus network space, promote the combination of traditional political and ideological education work and new media technology, guide teachers and students to strengthen the network awareness, and improve the quality of network civilization. Secondly, in addition to the integration of new technologies combined with the network, the school also needs to inherit and spread some excellent traditional culture. For example, the school can create some network cultural products that are popular with teachers and students, attract their attention and convey correct values. To cultivate the correct core values of socialism, teachers and students should be rooted in the excellent traditional culture of the Chinese nation, inheriting, innovating and developing the essence of [6]. Therefore, to optimize the network cultural environment of colleges and universities, we should base on the excellent traditional Chinese culture, optimize and improve the campus network cultural environment with the socialist core values, and inherit, innovate and spread the excellent traditional culture. 


\subsection{Strengthen the Construction of Teachers, Improve Teachers' Quality and Play an Exemplary Role}

Teachers play an irreplaceable role in the network education of colleges and universities. Therefore, in order to achieve the goal of education, teachers should not only have the comprehensive quality in line with the development of the times, but also strengthen the learning of new network technology. Teachers' work is to impart knowledge and cultivate talents. If they don't learn new knowledge and methods, they will not meet the needs of culture in today's society. Therefore, in today's increasingly developing society, teachers need to establish core values, improve the technical ability of new media and constantly acquire new knowledge through the network the ability of network construction is to educate and cultivate students in an all-round way with socialist core values. Secondly, colleges and universities can properly incline to the teachers who keep pace with the times and master the network technology when selecting and employing talents, so as to provide "hardware" support for the network education.

\subsection{Enrich Network Cultural Activities and Improve Students' Awareness of Correct Campus Network Culture}

In the era of new media, the ideological and political education in Colleges and universities should follow the law of students' healthy growth, keep pace with the times, and conform to the content of social development, so as to enrich the campus network cultural activities of college students. The lax supervision and freedom of speech in the field of network make the information on the Internet intermingle. Various values affect the thoughts of college students. College students' experience is still shallow, lack of identification of information, and easy to be affected by bad information. In view of this situation, colleges and universities must use core values to lead the development of the network, improve the network reward and punishment mechanism, strengthen the strength of network supervision, use legal means to suppress illegal websites, punish the publishers of bad information, resolutely resist the spread of bad information and wrong ideas, and create a good network environment for students.

The education department can also conduct a series of activities, such as network culture festival, keynote speech, publicity lecture, thematic class meeting, etc., to guide students to learn and apply, and combine theory with practice. Many colleges and universities in China have incorporated the strengthening of campus culture and education into their annual work arrangements. For example, Tianjin University of science and technology held its first campus network culture festival in 2016, covering more than ten activities in three categories, which has been actively participated in and unanimously praised by teachers and students. At the same time, it has strengthened the education of teachers and students' network culture in a relaxed environment, which has achieved a good result through the network In addition, colleges and universities can invite successful people from all walks of life and outstanding graduates to come to the University for communication, so as to achieve the purpose of educating students and transmitting advanced ideas by publicizing their deeds. Their deeds are novel and infectious to students, which are more likely to attract the attention of college students and guide them to participate in the network culture education and learning activities led by the socialist core values. Colleges and universities should focus on training a group of students who master high-level network technology, advanced ideas and collective consciousness, so that they can play a leading role in the class and guide more students to participate in it.

\section{Conclusion}

In a word, the rapid development of network has a great impact on the education of colleges and universities. Therefore, the promotion and development of network culture education in Colleges and universities has become the focus of Ideological and political education at this stage. In the Internet era, colleges and universities should fully understand the important leading value of socialist core values, strengthen the construction of Online Ideological and cultural positions, purify the campus 
network environment, promote students to form a correct world outlook, outlook on life and values, and improve the effectiveness of network education.

\section{Acknowledgments}

Stage achievements of the 2019 horizontal project of Xi'an Peihua University "Research on the training scheme of school enterprise cooperation information technology talents".

\section{References}

[1]. Liu Xin, Guo Hui, Hu Yanhui. Research on the guiding Countermeasures of teenagers' Internet public opinion based on the phenomenon of group polarization [J]. Office automation, 2015 (22): 33-36.

[2]. Ye Chong. The American Nie project in the age of network -- Taking the online edition of Miami Herald as an example [J]. Media, 2017 (2): 70-71.

[3]. Wei Fang, Zhang Guangsen. Ways and contents of online public opinion affecting ideological and Political Theory Course [J]. Research on Ideological and political education, 2016 (2): 115 119.

[4]. Alvin Toffler, Heidi Toffler, translated by Chen Feng. Creating a new civilization [M]. Shanghai: Sanlian bookstore, 2006:31. 